\title{
LOSS FUNCTIONS AND FRAMEWORK FOR REGIONAL FLOOD DAMAGE ESTIMATION IN RESIDENTIAL AREA
}

\author{
Jui-Lin Kang \\ Ph.D. Candidate, Department of Bioenvironmental Systems Engineering, National Taiwan University, Taipei, Taiwan \\ 10616 \\ Ming-Daw Su \\ Professor, Department of Bioenvironmental Systems Engineering, National Taiwan University, Taipei, Taiwan, 10617 \\ Ling-Fang Chang \\ Ph.D. Candidate, Department of Bioenvironmental Systems Engineering, National Taiwan University, Taipei, Taiwan \\ 10616.
}

Follow this and additional works at: https://jmstt.ntou.edu.tw/journal

Part of the Civil and Environmental Engineering Commons

\section{Recommended Citation}

Kang, Jui-Lin; Su, Ming-Daw; and Chang, Ling-Fang (2005) "LOSS FUNCTIONS AND FRAMEWORK FOR REGIONAL FLOOD DAMAGE ESTIMATION IN RESIDENTIAL AREA," Journal of Marine Science and Technology: Vol. 13: Iss. 3, Article 5.

DOI: $10.51400 / 2709-6998.2126$

Available at: https://jmstt.ntou.edu.tw/journal/vol13/iss3/5

This Research Article is brought to you for free and open access by Journal of Marine Science and Technology. It has been accepted for inclusion in Journal of Marine Science and Technology by an authorized editor of Journal of Marine Science and Technology. 


\section{LOSS FUNCTIONS AND FRAMEWORK FOR REGIONAL FLOOD DAMAGE ESTIMATION IN RESIDENTIAL AREA}

Acknowledgements

This study is part of the research results of the project NSC91-2625-Z-002-012 financially supported by Taiwan National Science Council. 


\title{
LOSS FUNCTIONS AND FRAMEWORK FOR REGIONAL FLOOD DAMAGE ESTIMATION IN RESIDENTIAL AREA
}

\author{
Jui-Lin Kang*, Ming-Daw Su**, and Ling-Fang Chang***
}

Key words: loss function, residential, flood damage, hazard management.

\section{ABSTRACT}

The risks of flooding damages for a region increase as the population and economy development increased in that area. Damage assessment and risk analysis are important issues for risk management and hazard mitigation. There are huge amount of data involved in the process of regional damage assessment and most of these data are spatially and temporally distributed. This paper focuses on the use of spatial data for capture of spatial characteristics of damage in natural calamities. Because it affects a large number of persons and families, flood damages in the residential area usually attract major attentions in regional flood hazard management. Stage-damage curve was built for the residential sector in this study based on socio-economic data such as persons per household, building characteristics, living styles, and common indoor decorations, furniture and appliances. Another objective of this paper is to demonstrate the use of geographic database and spatial analysis in regional flood damage assessments for capture of spatial variations within the region. A mapping scheme was proposed for estimation of buildings and residential area distributions using census data. The city of Taipei was used as a demonstration area for this study.

\section{INTRODUCTION}

Natural disasters such as flood and earthquake often cause major damages to the society especially when they occur in regions with high population and dense economic activities. Government usually has to spend huge budget for damage mitigation. Decisions in disaster mitigation usually have to depend on estimation of the cost of and the benefit from the action taken when budget is limited and competitive. For example, from the economic point of view, the government should

Paper Submitted 12/05/04, Accepted 03/30/05. Author for Correspondence: Ming-Daw Su.E-mail: sumd@ntu.edu.tw.

*Ph.D. Candidate, Department of Bioenvironmental Systems Engineering, National Taiwan University, Taipei, Taiwan 10616.

**Professor, Department of Bioenvironmental Systems Engineering, National Taiwan University, Taipei, Taiwan, 10617.

***Ph.D. Candidate, Department of Bioenvironmental Systems Engineering, National Taiwan University, Taipei, Taiwan 10616. not invest more money on a levee construction than the benefit from the project especially when the budget is limited. The benefit of a disaster mitigation project can be estimated from the difference of the expected damages before and after that project. This process is usually referred to as the "with-and-without analysis". This makes the damage assessment an important component in the process of risk management for calamities. Since the natural disasters usually impact wide area, there are huge amount of data involved in a regional damage assessment process and most of these data are spatially and temporally distributed. The damages for different land uses and different building types will not be the same under a same event of flood or earthquake. Estimation of damages by loss per unit area will cause the neglect of these spatial characteristics. The spatial distribution of population, damage intensities, land uses and building types should be properly preserved in the process of damage assessment.

A comprehensive flood management and mitigation system (as shown in Figure 1) is composed of hydrological module for surface runoff calculation, hydraulic model for channel routing and estimation of flooding extent and depths, economic module for dam-

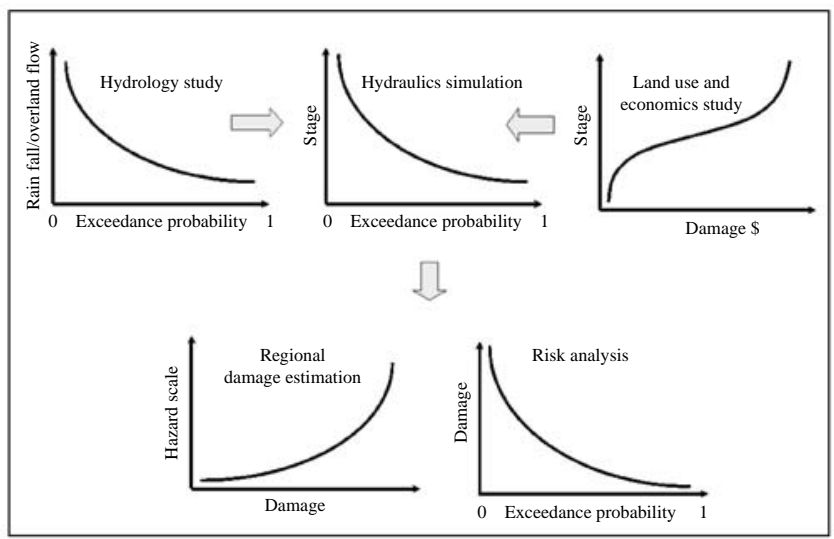

Fig. 1. The conceptual flow of a flood management and mitigation system. 
age assessment, and risk analysis module for regional risk appraisal [10].

Traditionally, flood damage was estimated by the loss per unit area [13, 19, 21,22]. Although in some of these studies, the flood area was divided into different land use types, there are no any considerations for the spatial variation of human activities. For example a single number of loss per unit area was applied on residential area leaving out the spatial differences among socio-economic factors such as income, expense, persons per household, living space footage and building types. Since the loss in residential sector is one of the major components of the regional flood damage, this paper is devoted to building the stage-damage curves (also referred to as loss functions) for residential sector. Geographic Information System (GIS) is used to take into account the spatial variations of socio-economic activities in this regional flood damage assessment process. The City of Taipei, as the most populated area in Taiwan, was chosen as study area. Surround by two major rivers of Kee-Lung River and Tan-Suie River, Taipei City suffered from frequent floods for quiet a long time until the flood mitigation project with a design flood of 200 year return period was completed.

\section{DEFINITION OF DAMAGES}

Damage is the amount of money to restore the area back to its original condition before the disaster [12]. The damage can be further categorized as direct damage, indirect damage, secondary damage, intangible damage, and uncertainty damage $[4,9,13]$ :

Direct damages: It is defined as the damages to structures, facilities, properties and casualties directly from the disaster itself. This tends to be the major portion to the regional damages and should receive most attention. And this will be the only one damage considered in this paper for the construction of stage-damage curve.

Indirect damages: The damages induced by the direct damages such as cost for changing the traffic route, and for shutting down of business, etc. The indirect damages are usually estimated by percentages of the direct damages [12].

Secondary damages: The losses to those whose properties are not directly damaged but may depend on the damaged service such as water treatment plant, hospital or library. The secondary damages usually tend to be offset by secondary benefits [12].

Intangible damages: Some items such as value of a historical site or environmental quality are very difficult to identify their monetary values and are categorized as intangible damages. The damage assessments for intangible items are often controversial and will be neglected in this study.

Uncertainty damages: It has been identified that people suffering from frequent flooding are willing to pay more insurance premiums than the expected annual losses [4]. The uncertainty damages estimation involves social and psychological studies.

\section{GEO-DATABASE FOR FLOOD DAMAGE ASSESSMENT}

There is a lot of spatial distributed information involved in regional flood damage assessment. This information includes topography, population, land use, building type and location. GIS was used in this study to build up geo-database and to do spatial analysis for a more rational algorithm for flood damage assessments.

\section{Digital terrain and flood potential map}

The Digital Terrain Model (DTM) with $40 \mathrm{~m}$ by $40 \mathrm{~m}$ resolution for the study area was collected (as shown in Figure 2). This DTM can be used with the hydraulic model for simulation of flooding extent and depths. Figure 3 is the simulated flood map for Taipei Metropolitan under a flooding event of a recurrent period of 20 years.

\section{Building type, locations and living styles}

Living styles, arrangement of indoor furniture and appliances may be dissimilar for families in different building types. A database of building features with a size of 300 thousands records maintained by the Building Administration Office of Taipei City Government was analyzed. The buildings were grouped into 5

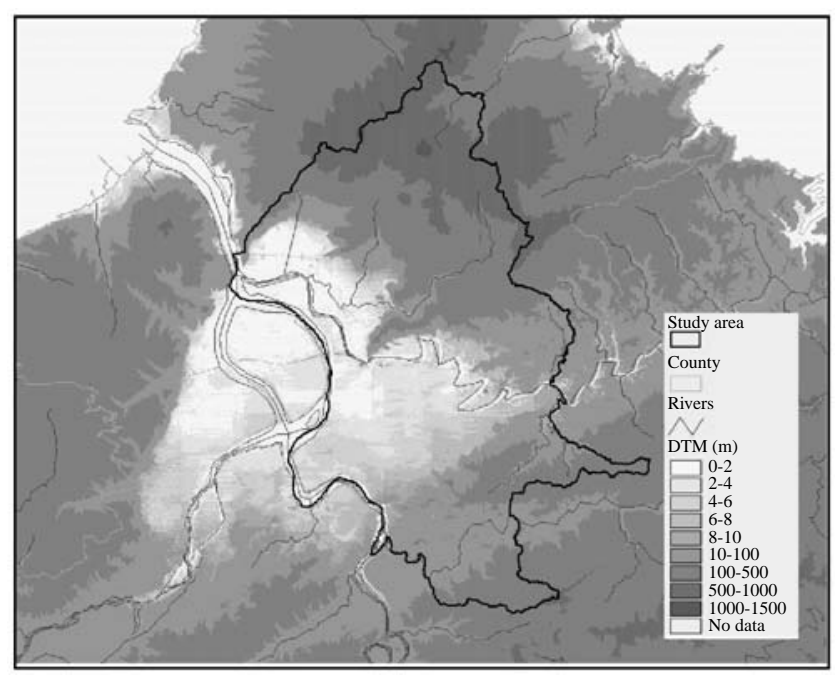

Fig. 2. Terrain map for Taipei metropolitan. 
categories: farmhouse, villa, town house, apartment, and mansion. The characteristics of each category were derived from the building database.

-Farmhouse: Single family, usually single floor with vast outdoor space for farming facilities and activities (such as a wide front yard to dry grains by the sun).

-Villa: Single family, 1-3 floors, with front or back yard for parking or gardening.

-Town House: one family per building, without front or back yard.

-Apartment ( $\geq 5$ stories): Multi-family dwelling with one family in each floor, usually not equipped without elevator.

-Apartment (6-11 stories): Multi-family dwelling, equipped with elevator.

-Mansion ( $\geq 12$ stories): Multi-family dwelling, equipped with elevator, basement parking, and public facilities.

Farmhouse, villa, and town house are single family dwelling with only one family living in a building. Because there is more than one family living in a building, apartments and mansions are categorized as multi-family dwellings. For single family dwelling with more than one floor, people in a frequently flooded region may arrange their major appliances and valuable furniture in the higher floors to avoid serious damages. Living style and characteristics such as floor square footage, number of rooms, and persons per household were estimated from the census and building database. These data were used to construct the model families. The average characteristics of each dwelling types are shown in Table 1. The locations of all the buildings in Taipei City as shown in Figure 4 were constructed in this study using the GIS address matching database.

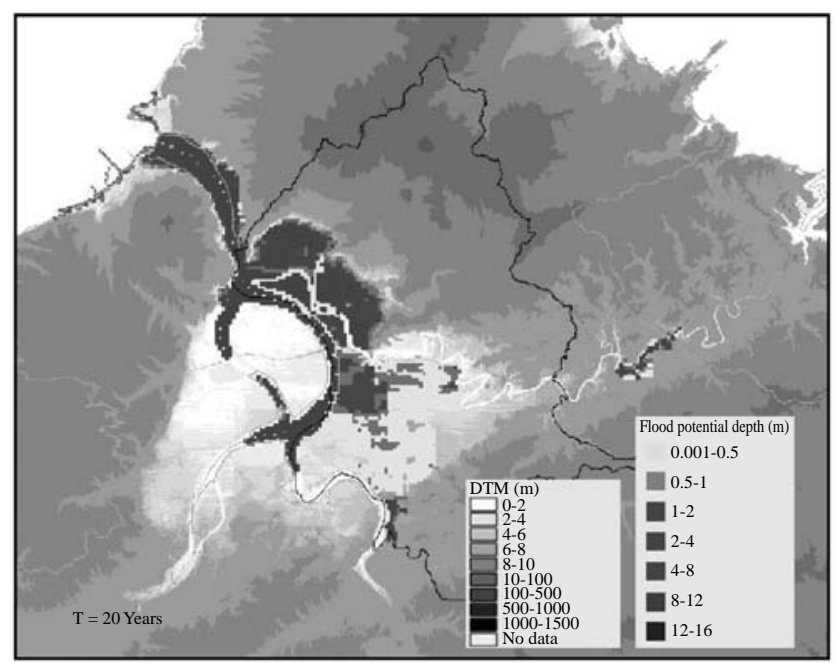

Fig. 3. Flooding simulation for Taipei City under a event of 20-years recurrent period.
This map overlaid with the flood map (as shown in Figure 3) can be used for estimating number of flooded buildings.

\section{Zoning map}

Zoning and land use information was collected for the study area and was used as a base to disaggregate the aggregated socio-economic data. Zoning map (as shown in Figure 5) shows spatial information of land use planning [14]. This map gives assistances in downscaling the spatial unit for socio-economic data from census tract level to a grid based cells. Zones that have no socio-economic activities on will not be used in this decomposition process for disaggregating socio-economic into a smaller grid cell system.

\section{STAGE-DAMAGE CURVE}

Stage-damage curves, also referred to as "flood loss functions" [5, 16, 17, 24, 25], were used for estimating the flood damage according to the flood depth. A stage-damage curve depicts the relationship of dam-

Table 1. Average dwelling characteristics in Taipei Metropoli$\tan$

\begin{tabular}{cccc}
\hline $\begin{array}{c}\text { Dwelling } \\
\text { type }\end{array}$ & $\begin{array}{c}\text { Families } \\
\text { per floor }\end{array}$ & $\begin{array}{c}\text { Floors per } \\
\text { building }\end{array}$ & $\begin{array}{c}\text { Footprint } \\
\left(\mathrm{m}^{2}\right)\end{array}$ \\
\hline Farmhouse & & 1 & 330 \\
Villa & & 4 & 66 \\
Town house & & 4 & 66 \\
Apartments ( $\leq 5$ floors) & 2 & 4 & 225 \\
Apartment (6-11 floors) & 3 & 7.4 & 337 \\
Mansion ( $\geq 12$ floors) & 4 & 12 & 449 \\
Mansion ( $\geq 13$ floors) & 5 & 15 & 561 \\
\hline
\end{tabular}

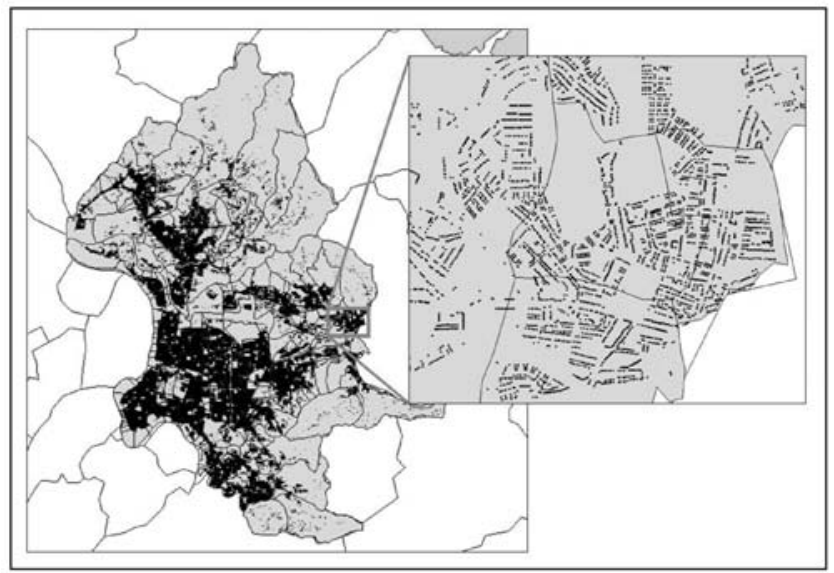

Fig. 4. Building locations Map of Taipei City. 
age varied with the flood depth (or stage). These curves are usually built for different human activities and have been used intensively for flood damage assessment [ 1 , $2,3,5,8,11,23]$. As shown in Figure 6, the stagedamage curve can be used for estimation of single building damage under different flood depth.

There are two typical approaches to the construction of the stage-damage curves. The first one is to use the flood damage data from field survey to derive the relationship of the flood damages to the flood depths. The second one is to synthesize the curve using a hypothetical model family which can represent a typical household in the region. The stage-damage curve in Figure 6 was constructed from tax deduction claim data for a flood hazard in Southern Taiwan in 1995. The data variances as shown in the figure are relatively large. Because approval for tax deduction application involves a great deal of red tape, people seldom make this claim except for major loss of single item like inundated vehicle. People tend not to report losses on furniture or appliances such as sofa or TV set to avoid the hassle in providing evidences of damage. Another reason is that people have different perception of the values for their damage assets especially for such things as art work or memorable items.

The synthetic approach was used in this study for constructing the stage-damage curves for residential. A model family with typical socio-economic characteristics such as floor square footage, persons per house hold, furniture and appliances, was established for both single and multiple family living types. The information about damages to these assets under different flood depths was collected from the interview to relevant mechanics, contractors, carpenter or workers. The stagedamage curves are then built by applying different flood depths to this model family and estimating the total

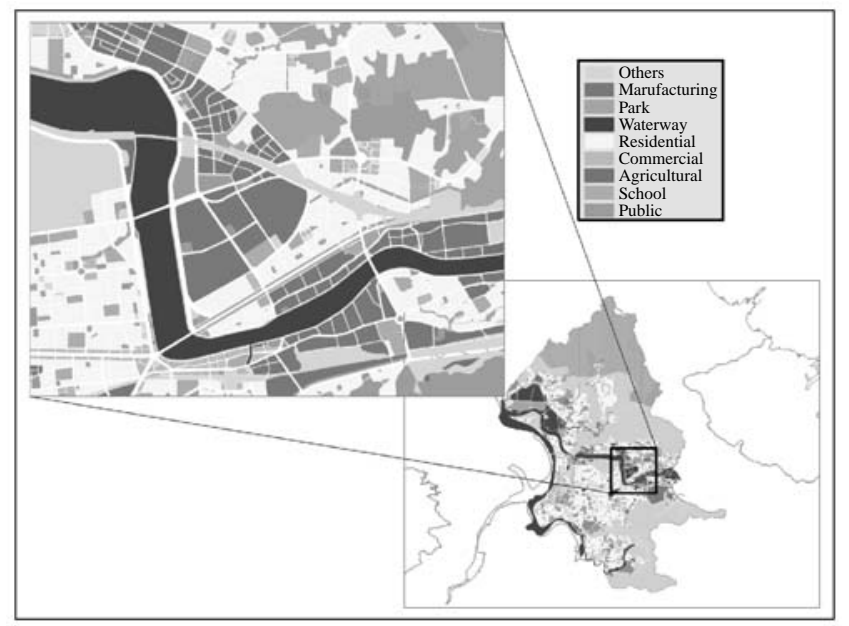

Fig. 5. Land use zoning Map of Taipei City. damages under these flood depths.

The survey of common possessed appliances in Taipei Metropolitan as shown in Table 2 is used as basis to establish the model families for this flooding damage assessment study [18]. The appliances with a possession rate greater than $40 \%$ were included in the arrangement of the model families. Items and numbers of furniture were determined from the average living floor square footage and persons per house hold. The price, dimension and the flood depth-damage relationships of furniture and appliances were acquired by market surveys and interviews with the service and repair department of major appliance supply corporations. Costs to restore the indoor area to its original condition, including cleaning and painting, were also identified through interviewing the local constructors.

The furniture and appliances were arranged in the model families at the usual position and height. The valuable assets, such as TV set and refrigerator, were moved to second or higher floor in multiple family housing to reduce loss in the flood. The previous constructed flood depth-damage relationship for each furniture and appliance through market survey and interviews with the service and repair department of major appliance companies were then summed up to create stage-damage curve for the model family of either single or multiple family dwellings. The resulting curves are shown in Figure 7.

\section{REGIONAL FLOOD DAMAGE ASSESSMENT}

The regional flood damage can be better estimated if the spatial variations of damage characteristics can be properly captured. The distribution of different land use should be preserved and damages in each category be estimated separately. This is also true in the flood damage estimations for residential area. Since different living style and building type have dissimilar damage characteristics in flooding events, they should be well

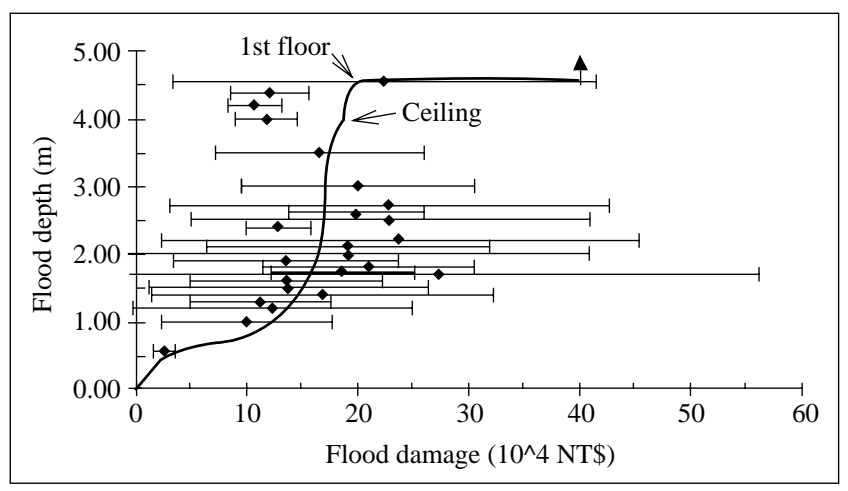

Fig. 6. Stage-damage curve of residential [20]. 
Table 2. Possession rate of appliances in Taipei Metropolitan

\begin{tabular}{cccc}
\hline Item & $(\%)$ & Item & $(\%)$ \\
\hline TV set & 99.36 & Cars & 53.12 \\
Phone & 99.16 & PC & 47.82 \\
Washer & 96.52 & Boiler & 46.11 \\
Exhaust fan (Kitchen) & 96.04 & Dehumidifier & 42.68 \\
Heater & 93.82 & Dryer & 33.57 \\
Air conditioner & 88.37 & Video game & 22.82 \\
Cable TV facilities & 73.52 & Fax & 22.39 \\
VCR & 72.27 & Piano and electric organ & 20.95 \\
Stereo set & 60.10 & Video camera & 17.52 \\
Motorcycle & 59.48 & Answering machine & 16.73 \\
Vacuum cleaner & 57.38 & Modem & 14.29 \\
Electro-magnetic range & 57.20 & Laser disc player & 10.40 \\
Microwave and oven & 57.02 & Dish washer & 7.16 \\
\hline
\end{tabular}

separated in the flood damage estimation processes.

The flood maps constructed through field investigation or by computer modeling can be overlaid with the building location map to find out the flooded buildings and their flood depths. The respective stage-damage curve was then applied for flood damage assessment of each building. The individual flood damages were summed up to generate the estimation for regional flood loss.

\section{MAPPING SCHEME BETWEEN POPULATION AND BUILDING DISTRIBUTION}

One of the major purposes for regional flood damage estimation is for risk management and hazard mitigation planning. "With-and-without analysis" can be used for economic evaluation on flood mitigation projects. Flood events used in with-and-without analysis usually are some simulated ones at projected time horizon in the future. Related data such as population and numbers and locations of buildings may be different from what they are at present and have to be estimated for the projected time frame. Although it is difficult to figure out the number and location of buildings for the future, future population is comparatively easy to be acquired. There are various population projecting models that can be employed for this purpose. Government also published numbers for future population projection [7]. A mapping scheme was proposed in this study to derive spatial distribution of buildings from regional population distribution. The conceptual flowchart of this mapping scheme is shown as in Figure 8.

The future population can first be estimated from the current registered residency or census data and the appropriate population projecting model. This

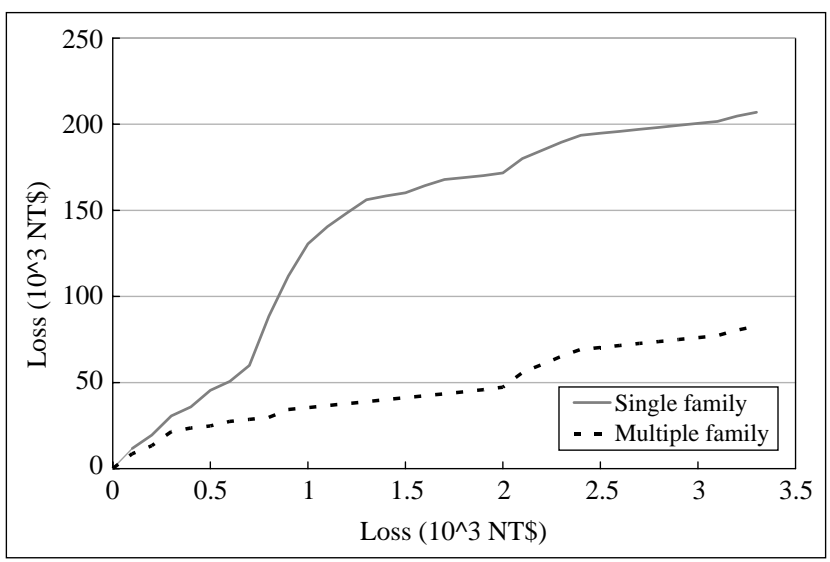

Fig. 7. Stage-damage curve for residential sector.

projected population is then used to estimate the number of household in the future by using the persons per household figure derived from the census database [6]. The average dwelling characteristics such as household per floor, floors per building, and footprint area as shown in Table 1 are used to estimate the total number of buildings in each census tract. These buildings are then assigned to the residential area according to the zoning map to simulate spatial variation of building in the future. Through the help of the zoning map and GIS analysis techniques, spatial variations of socioeconomic activities can be better captured. As shown in Figure 9, the distribution of population density without considering the zoning information is displayed. There shows no difference within each administrative unit. After taking into account the spatial information carried by the zoning map, the same data set can be presented in a more realistic way as shown in Figure 10. 


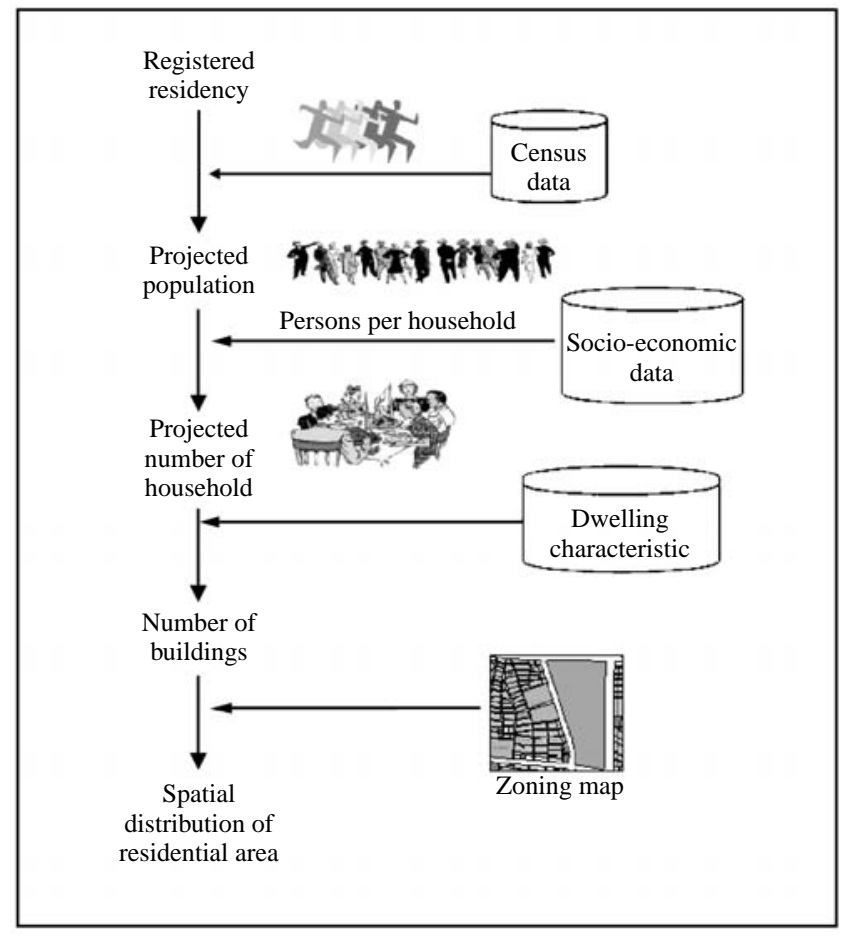

Fig. 8. Mapping scheme between population and building distribution.

\section{CONCLUSIONS AND DISCUSSIONS}

1. Geographic Information System was used in this study for geo-database implementation and spatial analysis. GIS manipulates spatially distributed data such as land use, population, buildings, etc. and captures their spatial variations for more realistic and rational regional flood damage assessments. The use of spatial data improves the traditional way of using unit area loss as a base for regional damage assessment.

2. The mapping scheme proposed in this study can be used to estimate the spatial distribution of socioeconomic data in the future for feasibility study of flood mitigation projects. This mapping is done through the use of projected population which is more available from government and related agencies. With the help of zoning information, the proposed mapping algorithm can better realized the probable spatial variation of the interested socio-economic data.

3. The flood damages estimated as descried were using stage-damage curve constructed from current data. If the same evaluation process will be done in the future, the damages estimated should be adjusted to take the temporal effect into account. One way to do this adjustment is through the use of price indices [15].

4. Since the stage-damage curves were derived from the data for the study area, they may be site-dependent. It

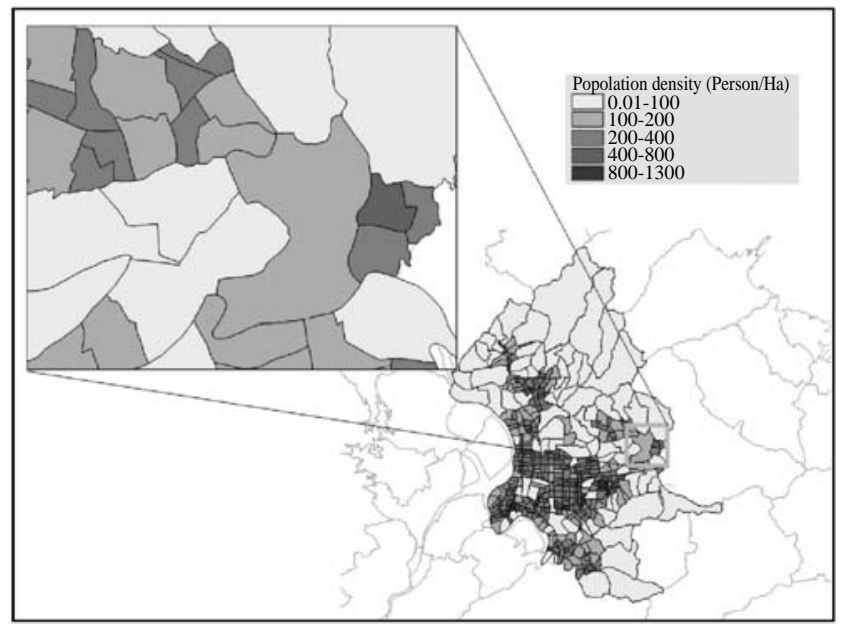

Fig. 9. Population density by administrative units.

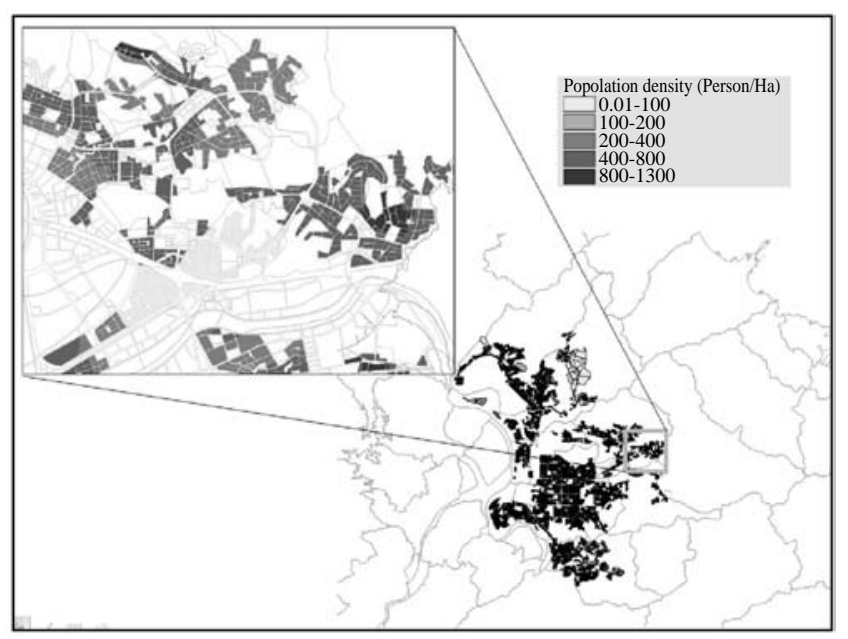

Fig. 10. Population density distribution with zoning information.

should be cautious if the curves are to be used for other sites. It is suggested that the stage-damage curves be transformed into dimensionless curves by dividing the figures in both axes by the maximum damages and flood depths respectively. Otherwise, a regional adjusting factor should be established to accommodate the economic difference between the target area and the area used in this study. Land values, family expense, and tax data are candidate factors for this regional correction.

\section{ACKNOWLEDGEMENTS}

This study is part of the research results of the project NSC91-2625-Z-002-012 financially supported by Taiwan National Science Council. 


\section{REFERENCES}

1. Arnell, N.W., "Expected Annual Damage and Uncertainties in Flood Frequency Estimation," J. Water Res. Pl., Vol. 115, No. 1, pp. 94-107 (1989).

2. Berning, C., Viljoen, M.F., and DuPlessis, L.A., "Loss Function for Sugar-cane: Depth and Duration of Inundation as Determinates of Extent of Flood Damage," Water SA, Vol. 26, No. 4, pp. 527-530 (2000).

3. Boyle, S.J., Tsanis, I.K., and Kanaroglou, P.S., "Developing Geographic Information Systems for Land Use Impact Assessment in Flooding Conditions," J. Water Res. Pl., Vol. 124, No. 2, pp. 89-98 (1998).

4. Breaden, J.P., The Generation of Flood Damage Time Sequences (Research Paper No. 32), University of Kentucky, Water Resources Institute, Lexington, KY (1973).

5. Dutta, D., Herath, S., and Musiake, K., "A Mathematical Model for Flood Loss Estimation," J. Hydrol., Vol. 277, pp. 24-49 (2003).

6. Executive Yuan, Census Data 1980, Taipei, Taiwan (1980).

7. Executive Yuan, Population Growth Estimates 1998 2051, Taipei, Taiwan (1999).

8. Goldman, D., "Estimating Expected Annual Damage for Levee Retrofits," J.Water Res. Pl., Vol. 123, No. 2, pp. 89-94 (1997).

9. Grigg, N.S., Urban Drainage and Flood Control Projects Economic: Legal and Financial Aspects, Colorado State University, Fort Collins, CO (1976).

10. Grigg, N.S., Water Resources Planning, McGraw-Hill, New York (1985).

11. Grigg, N.S., Water Resources Managment, McGrawHill, New York (1996).

12. Grigg, N.S. and Heiweg, O.J., Estimating Direct Residential Flood Damage in Urban Areas, Colorado State
University, Fort Collins, CO (1974).

13. Grigg, N.S. and Heiweg, O.J., "State-of-the-Art of Estimating Flood Damage in Urban Areas," Water Resour. Bull., Vol. 11, No. 2, pp. 379-391 (1975).

14. Ministry of Interior, Investigation Report for National Land Use Investigation, Taipei, Taiwan (1997).

15. Ministry of Interior, Urban Real Estate Price Indices, Taipei, Taiwan (2000).

16. Penning-Rowsell, E.C. and Chatterton, J.B., The Benefits of Flood Alleviation: A Manual of Assessment Techniques, Gower Aldershot, England (1977).

17. Smith, D.I., "Flood Damage Estimation-A Review of Urban Stage-Damage Curves and Loss Functions," Water SA, Vol. 20, No. 3, pp. 231-238 (1994).

18. Taipei City Government, Year Book of Taipei, Taipei, Taiwan (1999).

19. Taiwan Water Conservancy, Planning of Yen-Shui Stream, Taipei, Taiwan (1998).

20. Taiwan Water Resource Agency, National Flood Insurance Program Pilot Study: A Case Studies and for TangDee-Yang Area (Project Report), Taipei, Taiwan (1997).

21. Tsai, C.T., GIS Applications on Flood Warning System (II), National Cheng Kung University, Tainan, Taiwan (1994).

22. Tsai, C.T., GIS Applications on Flood Warning System (III), National Cheng Kung University, Tainan, Taiwan, (1995).

23. U.S. Army Corps of Engineers, Post Flood Assessment, Sacramento, CA (1999).

24. White, G.F., Human Adjustment to Floods (Research Paper No. 29), University of Chicago, Department of Geography, Chicago, IL (1945).

25. White, G.F., Choice of Adjustments to Floods (Research Paper No. 93), University of Chicago, Department of Geography, Chicago, IL (1964). 